\title{
Staphylococcus massiliensis sp. nov., isolated from a human brain abscess
}

Correspondence

Véronique Roux

vroux91@live.fr

\author{
Mouhamad Al Masalma, Didier Raoult and Véronique Roux
}

Laboratoire de Bactériologie - Virologie, Hôpital de la Timone, URMITE CNRS-IRD UMR 6236, IFR48, 264 rue Saint-Pierre, 13385 Marseille, Cedex 05, France

\begin{abstract}
Gram-positive, catalase-positive, coagulase-negative, non-motile, non-fermentative and novobiocin-susceptible cocci were isolated from a human brain abscess sample (strain $\left.5402776^{\top}\right)$. This novel strain was analysed by a polyphasic taxonomic approach. The respiratory quinones detected were MK-7 (93\%) and MK-6 (7\%) and the major fatty acids were $\mathrm{C}_{15: 0}$ iso $(60.5 \%), \mathrm{C}_{17: 0}$ iso $(8.96 \%) \mathrm{C}_{15: 0}$ anteiso $(7.93 \%)$ and $\mathrm{C}_{19: 0}$ iso $(6.78 \%)$. The peptidoglycan type was A3 $\alpha$ L-Lys-Gly $2-3-$ L-Ser-Gly. Based on cellular morphology and biochemical criteria, the new isolate was assigned to the genus Staphylococcus, although it did not correspond to any recognized species. The $\mathrm{G}+\mathrm{C}$ content of the DNA was $36.6 \mathrm{~mol} \%$. Phylogenetic analysis based on 16S rRNA gene sequence comparisons showed that the new isolate was most closely related to Staphylococcus piscifermentans, Staphylococcus condimenti, Staphylococcus carnosus subsp. carnosus, S. carnosus subsp. utilis and Staphylococcus simulans $(97.7 \%, 97.6 \%$, $97.6 \%, 97.6 \%$ and $96.5 \%$ sequence similarity, respectively). Comparison of tuf, hsp60, rpoB, $d n a J$ and $\operatorname{sod} A$ gene sequences was also performed. In phylogenetic analysis inferred from tuf, dnaJ and rpoB gene sequence comparisons, strain $5402776^{\top}$ clustered with Staphylococcus pettenkoferi (93.7\%, $82.5 \%$ and $89 \%$ sequence similarity, respectively) and on phylogenetic analysis inferred from sodA gene sequence comparisons, it clustered with Staphylococcus chromogenes (82.8\%). On the basis of phenotypic and genotypic data, this isolate represents a novel species for which the name Staphylococcus massiliensis sp. nov. is proposed (type strain $5402776^{\top}=$ CCUG $55927^{\top}=$ CSUR P23 $^{\top}$ ).
\end{abstract}

Staphylococci are ubiquitous bacteria in nature that are able to colonize or infect a wide range of animals. Currently the genus Staphylococcus consists of more than 50 recognized species and subspecies. Coagulase-positive Staphylococcus aureus subsp. aureus and coagulase-negative staphylococci are among the most commonly isolated bacterial species in the clinical microbiology laboratory. Coagulase-negative staphylococci have long been regarded as skin commensals and their role as pathogens has been recognized only recently, especially in patients with indwelling devices such as prosthetic valves and catheters (Huebner \& Goldmann, 1999; Von Eiff et al., 2002). During the last decade, several coagulase-negative staphylococci have been isolated from animals (Pantůček et al., 2005; Spergser et al., 2003) and clinical samples (Trülzsch et al., 2007; Zakrzewska-Czerwinska et al., 1995). In this report, we describe a novel coagulase-negative

The GenBank/EMBL/DDBJ accession number for the 16S rRNA sequence of Staphylococcus massiliensis sp. nov. $5402776^{\top}$ is EU707796.

Additional phylogenetic trees based on tuf, hsp60, rpoB, dnaJ and $\operatorname{sod} A$ gene sequences are available as supplementary figures with the online version of this paper. species belonging to the genus Staphylococcus that was isolated from a human brain abscess sample.

In December 2005, a 52-year-old man underwent neurosurgical intervention for the treatment of a brain tumour. He developed fever, headache and an aggravation of existing neurological symptoms. Magnetic resonance imaging and computerized tomography revealed a frontal brain abscess. Antibiotic therapy was begun with a combination of imipenem, gentamicin and vancomycin. The abscess was drained and samples of the pus were sent to our laboratory for cultural and molecular investigations. A bacterial strain was isolated on blood agar at $37^{\circ} \mathrm{C}$ in an aerobic atmosphere. Gram staining revealed Gram-positive cocci that occurred singly, in pairs and in clusters. The isolate (strain $5402776^{\mathrm{T}}$ ) was identified using a Vitek 2 instrument and Gram-positive card (bioMérieux) as Leuconostoc mesenteroides subsp. cremoris with a probability of $93 \%$. API 20 Staph strip inoculation (bioMérieux) was performed and an identification of Kocuria varians was obtained. 16S rRNA gene sequence determination was conducted and a comparison with the GenBank database showed that strain $5402776^{\mathrm{T}}$ was a member of the genus Staphylococcus. It was initially suspected to be a contaminant because it was sensitive to gentamicin and vancomycin. 
Antimicrobial susceptibility was determined according to the CLSI (formerly National Committee for Clinical Laboratory Standards; NCCLS) criteria. The novel isolate was sensitive to oxacillin, gentamicin, clindamycin, ofloxacin, rifampicin, fosfomycin, vancomycin, teicoplanin and trimethoprim/sulfamethoxazole. The strain showed intermediate susceptibility to fusidic acid.

Colony morphology and haemolytic activity were observed after $48 \mathrm{~h}$ growth on $5 \%$ sheep blood agar at $37^{\circ} \mathrm{C}$. Colonies were white, glossy, circular, bulging, nonhaemolytic and 1-3 mm in diameter. Growth was tested at different temperatures $\left(25,30,37,45\right.$ and $\left.50{ }^{\circ} \mathrm{C}\right)$ using sheep blood agar. Growth occurred between $25{ }^{\circ} \mathrm{C}$ and $45{ }^{\circ} \mathrm{C}$, but optimum growth was obtained at $37^{\circ} \mathrm{C}$. Growth was tested in an anaerobic atmosphere created using the GENbag anaer incubation system (bioMérieux), a microaerophilic atmosphere created using the GENbag microaer incubation system, in the presence of air and also in the presence of $5 \% \mathrm{CO}_{2}$. Growth occurred in all atmospheres but was weak in microaerophilic and anaerobic atmospheres. Growth in different $\mathrm{NaCl}$ concentrations was tested in trypticase soy broth (TSB; Becton Dickinson) supplemented with 2, 5, 7, 10 and $15 \%(\mathrm{w} / \mathrm{v}) \mathrm{NaCl}$. The novel strain was able to grow in $\mathrm{NaCl}$ concentrations from $2 \%$ to $15 \%(\mathrm{w} / \mathrm{v})$.

The size and ultrastructure of the cells were determined by electron microscopy. Cells were grown in liquid TSB medium for $48 \mathrm{~h}$ at $37{ }^{\circ} \mathrm{C}$ and stained with $1 \%(\mathrm{w} / \mathrm{v})$ phosphotungstic acid. The samples were examined using a transmission electron microscope (Morgagni 268D; Philips) at an operating voltage of $60 \mathrm{kV}$. The cells were cocci of $0.5-0.8 \mu \mathrm{m}$ in diameter.

Coagulase activity was investigated using Staph Aureus Fumouze kit (Fumouze Diagnostics) and was negative. Catalase activity was determined by the ID colour catalase test kit (bioMérieux) and was positive. Oxidase activity was assayed by applying the cells to moistened discs impregnated with dimethyl-p-phenylene diamine (bioMérieux) and was negative. Clumping factor activity was investigated using the Slidex Staph Plus test (bioMérieux) and was negative. Biochemical characteristics were determined using API ZYM strips, API $50 \mathrm{CH}$ strips combined with API $50 \mathrm{CHB} / \mathrm{E}$ medium, API 20 Staph strips and ID 32 Staph strips (bioMérieux) according to the manufacturer's instructions. Additional characteristics were tested using the Biolog system. Bacterial growth was obtained on BUG (Biolog Universal Growth) agar + blood (Biolog) medium. Suspension of the bacterial cells was performed using sterile GP/GN inoculation fluid (Biolog) and samples were dispensed to GP2 Microplates (Biolog) according to the manufacturer's instructions. Incubation was carried out at $36{ }^{\circ} \mathrm{C}$ in an aerobic atmosphere for $21 \mathrm{~h}$.

The phenotypic characteristics of the novel strain were compared with those of Staphylococcus piscifermentans CIP $103958^{\mathrm{T}}$, Staphylococcus condimenti CIP $105760^{\mathrm{T}}$, Staphylococcus carnosus subsp. carnosus CIP $103274^{\mathrm{T}}$ and
S. carnosus subsp. utilis CIP $105758^{\mathrm{T}}$, which were identified as the most closely related species by $16 \mathrm{~S}$ rRNA gene sequence analysis, and with those of Staphylococcus pettenkoferi CIP $107711^{\mathrm{T}}$ and Staphylococcus chromogenes CIP $81.59^{\mathrm{T}}$, which were identified as the most closely related species when $t u f, r p o B, d n a J$ gene sequences and $\operatorname{sod} A$ gene sequences were analysed, respectively. The distinctive traits of the novel isolate are presented in Table 1 and Table 2. The results of additional tests are given in the species description. Phenotypically, the most closely related strain to strain $5402776^{\mathrm{T}}$ was $S$. pettenkoferi CIP $107711^{\mathrm{T}}$ but differences were apparent for acid production from glycerol, D-glucose, D-fructose, sucrose and trehalose. Differences were also noted for enzymic activities such as esterase (C4), esterase lipase (C8) and acid phosphatase. Nitrate reduction was positive for strain $5402776^{\mathrm{T}}$ but was negative for S. pettenkoferi CIP $107711^{\mathrm{T}}$.

Analysis of respiratory quinones by HPLC and polar lipids by two-dimensional TLC was carried out by the DSMZ Identification Service and Dr Brian Tindall, DSMZ, Braunschweig, Germany. Respiratory lipoquinones were extracted from $100 \mathrm{mg}$ freeze-dried cell material as described by Tindall (1990a, b). Respiratory lipoquinones were separated into their different classes (menaquinones and ubiquinones) by TLC on silica gel, using hexane: tertbutylmethylether $(9: 1, \mathrm{v} / \mathrm{v})$ as the solvent. UV-absorbing bands corresponding to menaquinones or ubiquinones were removed from the plate and further analysed by HPLC at $269 \mathrm{~nm}$. The respiratory quinones were MK-7 $(93 \%)$ and MK-6 (7\%). Preparation and determination of cellular fatty acids were carried out according to the procedures given for the Sherlock Microbial identification system (MIDI). The major fatty acids were $\mathrm{C}_{15: 0}$ iso $(60.5 \%), \mathrm{C}_{17: 0}$ iso $(8.96 \%), \mathrm{C}_{15: 0}$ anteiso $(7.93 \%)$ and $\mathrm{C}_{19: 0}$ iso $(6.78 \%)$. The determination of the peptidoglycan structure was carried out as described by Schleifer (1985) and Schleifer \& Kandler (1972) with the modification that TLC on cellulose was applied instead of paper chromatography. Quantitative analysis of amino acids was performed after derivatization by GC and GC/MS according to MacKenzie (1987). The total hydrolysate $(4 \mathrm{M} \mathrm{HCl}, 16 \mathrm{~h}$, $100{ }^{\circ} \mathrm{C}$ ) of the peptidoglycan contained the amino acids lysine (Lys), alanine (Ala), glycine (Gly), serine (Ser) and glutamic acid (Glu) in molar ratios of around $1.0: 1.5: 3.5: 0.9: 1.0$. The identity of the amino acids was confirmed by GC/MS. The partial hydrolysate $(4 \mathrm{M} \mathrm{HCl}$, $0.75 \mathrm{~h}, 100{ }^{\circ} \mathrm{C}$ ) of the peptidoglycan contained (in addition to the amino acids) the peptides $\mathrm{L}-\mathrm{Ala} \rightarrow \mathrm{D}-\mathrm{Glu}$, Gly $\rightarrow$ Gly, Gly $\longrightarrow$ L-Lys, L-Lys $\longrightarrow$ D-Ala and Gly $\rightarrow$ L-Lys $\rightarrow$ DAla. It was concluded that strain $5402776^{\mathrm{T}}$ showed the A3 $\alpha$ L-Lys-Gly ${ }_{2-3}-\mathrm{L}-\mathrm{Ser}-\mathrm{Gly}$ peptidoglycan type (type A11.3 according to http://www.dsmz.de/microorganisms/main. php?content $\mathrm{id}=35$ ). The interpeptide bridge, consisting of oligoglycine peptides, was characteristic of the genus Staphylococcus. The DNA G + C content was determined by using the HPLC method of Mesbah et al. (1989). The value found for strain $5402776^{\mathrm{T}}$ was $36.6 \mathrm{~mol} \%$. 
Table 1. Characteristics that differentiate the novel strain from the different species tested in this study

Taxa: 1, strain $5402776^{\mathrm{T}}$; 2, S. pettenkoferi CIP $107711^{\mathrm{T}}$; 3, S. chromogenes CIP $81.59^{\mathrm{T}}$; 4, S. piscifermentans CIP $103958^{\mathrm{T}}$; 5 , S. condimenti CIP $105760^{\mathrm{T}}$; 6, S. carnosus subsp. carnosus CIP $103274^{\mathrm{T}}$; 7, S. carnosus subsp. utilis CIP $105758^{\mathrm{T}}$. +, Positive; -, negative; w, weakly positive.

\begin{tabular}{|c|c|c|c|c|c|c|c|c|c|c|c|c|c|c|}
\hline \multirow[b]{2}{*}{ Characteristic } & \multicolumn{2}{|c|}{1} & \multicolumn{2}{|c|}{2} & \multicolumn{2}{|c|}{3} & \multicolumn{2}{|c|}{4} & \multicolumn{2}{|c|}{5} & \multicolumn{2}{|c|}{6} & \multicolumn{2}{|c|}{7} \\
\hline & $24 \mathrm{~h}$ & $48 \mathrm{~h}$ & $24 \mathrm{~h}$ & $48 \mathrm{~h}$ & $24 \mathrm{~h}$ & $48 \mathrm{~h}$ & $24 \mathrm{~h}$ & $48 \mathrm{~h}$ & $24 \mathrm{~h}$ & $48 \mathrm{~h}$ & $24 \mathrm{~h}$ & $48 \mathrm{~h}$ & $24 \mathrm{~h}$ & $48 \mathrm{~h}$ \\
\hline \multicolumn{15}{|c|}{ Acid production from (API $50 \mathrm{CH}$ ): } \\
\hline$N$-Acetylglucosamine & - & - & - & - & $\mathrm{W}$ & + & + & + & + & + & + & + & $\mathrm{W}$ & + \\
\hline Aesculin & - & - & - & - & - & - & + & + & - & - & - & - & - & - \\
\hline Arbutin & - & - & - & - & - & - & $\mathrm{W}$ & + & - & - & - & - & - & - \\
\hline D-Fructose & - & - & $\mathrm{W}$ & + & + & + & - & + & + & + & + & + & + & + \\
\hline D-Galactose & - & - & - & - & + & + & + & + & $\mathrm{w}$ & + & $\mathrm{w}$ & + & - & - \\
\hline D-Glucose & - & - & $\mathrm{W}$ & + & + & + & + & + & + & + & + & + & + & + \\
\hline Glycerol & - & - & - & $\mathrm{W}$ & $\mathrm{W}$ & + & - & - & - & - & $\mathrm{W}$ & + & - & - \\
\hline D-Lactose & - & - & - & - & + & + & + & + & + & + & + & + & - & - \\
\hline Maltose & - & - & - & - & - & - & + & + & - & - & - & - & - & - \\
\hline D-Mannitol & - & - & - & - & - & - & - & - & $\mathrm{w}$ & + & + & + & - & - \\
\hline D-Mannose & - & - & - & - & + & + & - & - & + & + & + & + & - & - \\
\hline Melezitose & - & - & - & - & - & - & + & + & - & - & - & - & - & - \\
\hline D-Ribose & - & - & - & - & + & + & - & - & - & + & - & - & - & - \\
\hline D-Sorbitol & - & - & - & - & - & - & - & - & $\mathrm{w}$ & + & $\mathrm{w}$ & + & - & - \\
\hline Sucrose & - & - & - & $\mathrm{W}$ & + & + & + & + & - & - & - & - & - & - \\
\hline Trehalose & - & - & - & $\mathrm{W}$ & + & + & + & + & + & + & + & + & + & + \\
\hline Turanose & - & - & - & - & - & - & $\mathrm{w}$ & + & - & - & - & - & - & - \\
\hline \multicolumn{15}{|l|}{ Enzyme activities: } \\
\hline Acid phosphatase & - & & + & & + & & + & & + & & + & & + & \\
\hline Alkaline phosphatase & - & & - & & + & & - & & + & & + & & - & \\
\hline Arginine dihydrolase & - & & - & & + & & + & & + & & + & & + & \\
\hline Esterase (C4) & $\mathrm{W}$ & & + & & + & & + & & + & & + & & + & \\
\hline Esterase lipase (C8) & $\mathrm{W}$ & & + & & $\mathrm{w}$ & & + & & + & & + & & - & \\
\hline$\beta$-Galactosidase & - & & - & & - & & + & & + & & + & & - & \\
\hline$\alpha$-Glucosidase & - & & - & & - & & + & & - & & - & & + & \\
\hline$\beta$-Glucosidase & - & & - & & - & & + & & - & & - & & - & \\
\hline $\begin{array}{l}\text { Naphthol-AS-BI- } \\
\text { phosphohydrolase }\end{array}$ & - & & - & & - & & - & & - & & + & & $\mathrm{W}$ & \\
\hline Urease & - & & - & & - & & + & & + & & - & & - & \\
\hline Resistance to novobiocin & - & & - & & - & & + & & + & & + & & + & \\
\hline Nitrate reduction & + & & - & & + & & + & & + & & + & & + & \\
\hline
\end{tabular}

For nucleotide sequence analysis, bacterial DNA was extracted using the MagNA Pure LC DNA isolation kit III (Roche) with the MagNA Pure LC instrument as described by the manufacturer. the 16S rRNA gene was PCR-amplified using the universal primer pair fD1 and rp2 (Weisburg et al., 1991). The tuf, hsp60, rpoB, dnaJ and sodA genes were also PCR-amplified as previously described (Ghebremedhin et al., 2008; Shah et al., 2007). PCR products were purified using the NucleoFast 96 PCR kit (Macherey-Nagel) according to the manufacturer's recommendations. Sequencing reactions were carried out using the Big Dye Terminator, version 1.1, cycle sequencing kit (Perkin-Elmer) according to the manufacturer's instructions. Sequencing products were purified and sequences were analysed on an ABI PRISM 3130x Genetic Analyzer (Applied Biosystems). The sequences obtained were compared with database sequences (GenBank) using BLAST. Gene sequences were aligned using the multisequence alignment program CLUSTAL_X (1.8). Phylogenetic relationships with closely related species were determined using MEGA version 4 (Tamura et al., 2007). Distance matrices were determined following the assumptions described by Kimura (1980) and were used to elaborate dendrograms using the neighbour-joining method (Saitou \& Nei, 1987). The maximum-parsimony algorithm was also used to infer phylogenetic relationships. A bootstrap analysis was performed to investigate the stability of the tree obtained. Bootstrap values were obtained for a consensus tree based on 100 randomly generated trees. The tree topology was the same with the two methods.

Based on 16S rRNA sequence comparisons, a value $\leqslant 97 \%$ has been suggested as the threshold to separate species (Stackebrandt et al., 2002). However, increasingly, novel species have been described with higher similarity values (Kuisiene et al., 2008; Mun et al., 2008; Song et al., 2007; Zhou et al., 2008) and recently Stackebrandt \& Ebers 


\section{Table 2. GP2 MicroPlate results}

Taxa: 1, strain $5402776^{\mathrm{T}}$; 2, S. pettenkoferi CIP $107711^{\mathrm{T}} ; 3$, S. chromogenes CIP $81.59^{\mathrm{T}}$; 4, S. piscifermentans CIP $103958^{\mathrm{T}}$; 5, S. condimenti CIP $105760^{\mathrm{T}}$; 6, S. carnosus subsp. carnosus CIP $103274^{\mathrm{T}}$; 7, S. carnosus subsp. utilis CIP $105758^{\mathrm{T}}$. +, Positive; -, negative; $\mathrm{W}$, weakly positive; $\mathrm{V}$, variable.

\begin{tabular}{|c|c|c|c|c|c|c|c|}
\hline Characteristic & 1 & 2 & 3 & 4 & 5 & 6 & 7 \\
\hline Acetic acid & - & - & - & - & - & - & + \\
\hline $\mathrm{N}$-Acetyl-D-glucosamine & - & - & - & - & - & + & + \\
\hline Adenosine & + & - & - & + & - & + & + \\
\hline Adenosine $5^{\prime}$-monophosphate & - & - & - & - & - & + & - \\
\hline L-Alaninamide & $\mathrm{V}$ & - & - & - & - & - & - \\
\hline D-Alanine & - & - & - & + & + & $\mathrm{V}$ & + \\
\hline L-Alanyl glycine & - & - & - & + & - & - & + \\
\hline L-Arabinose & $\mathrm{w}$ & - & - & - & - & - & + \\
\hline D-Arabitol & - & - & - & + & - & - & - \\
\hline $2^{\prime}$-Deoxyadenosine & + & - & - & + & - & + & + \\
\hline Dextrin & - & - & - & + & + & + & + \\
\hline D-Fructose 6-phosphate & - & + & - & - & - & - & - \\
\hline D-Fructose & - & - & + & + & + & + & + \\
\hline D-Galactose & - & - & - & + & $\mathrm{V}$ & - & - \\
\hline D-Gluconic acid & - & - & - & + & + & + & - \\
\hline D-Glucose 6-phosphate & - & + & - & - & - & - & - \\
\hline L-Glutamic acid & + & + & - & + & + & - & + \\
\hline DL- $\alpha$-Glycerol phosphate & - & - & - & + & + & - & - \\
\hline$\alpha$-Hydroxybutyric acid & - & - & + & - & - & - & + \\
\hline$\gamma$-Hydroxybutyric acid & - & - & - & $\mathrm{V}$ & - & - & - \\
\hline Inosine & $\mathrm{w}$ & - & - & - & - & + & + \\
\hline$\alpha$-Ketovaleric acid & + & + & + & + & $\mathrm{w}$ & + & + \\
\hline D-Lactic acid methyl ester & - & - & - & - & $\mathrm{V}$ & - & - \\
\hline Maltose & - & - & - & + & - & - & - \\
\hline Maltotriose & - & - & - & + & - & - & - \\
\hline D-Mannitol & - & - & - & - & - & + & - \\
\hline D-Mannose & - & - & + & - & + & + & - \\
\hline Melezitose & - & - & - & + & - & - & - \\
\hline$\beta$-Methyl D-glucoside & - & - & + & - & - & - & - \\
\hline 3-Methyl D-glucose & - & - & - & - & + & + & + \\
\hline D-Psicose & - & - & + & + & + & + & + \\
\hline L-Pyroglutamic acid & + & - & - & + & - & $\mathrm{V}$ & - \\
\hline D-Ribose & + & - & + & + & + & + & + \\
\hline L-Serine & + & - & + & + & + & + & + \\
\hline Sucrose & - & + & + & + & - & - & - \\
\hline Thymidine & - & - & - & + & + & + & + \\
\hline Thymidine $5^{\prime}$-monophosphate & - & - & - & - & $\mathrm{V}$ & + & - \\
\hline Trehalose & - & + & + & + & + & + & + \\
\hline Turanose & - & - & - & + & - & - & $\mathrm{v}$ \\
\hline Tween 40 & - & - & - & - & - & - & + \\
\hline Uridine & - & - & - & + & + & + & + \\
\hline Uridine $5^{\prime}$-monophosphate & - & - & - & - & + & + & - \\
\hline D-Xylose & - & - & + & - & - & - & + \\
\hline
\end{tabular}

(2006) proposed that a cut-off value of $98.7 \%$ should be applied to define novel species on the basis of $16 \mathrm{~S}$ rRNA gene sequence comparisons. This new cut-off value was confirmed by Achtman \& Wagner (2008). Based on $16 \mathrm{~S}$ rRNA gene sequence similarity (calculated with MEGA version 4), the highest value between the novel strain and other species of the genus Staphylococcus was $97.7 \%$ with $S$. piscifermentans. The similarity values between the novel strain and recognized species of the genus Staphylococcus ranged from $99.9 \%$ to $95.8 \%$ (median value, $97.3 \%$ ). Based on 16S rRNA gene sequence comparisons, strain $5402776^{\mathrm{T}}$ represented a novel species of the genus Staphylococcus (Fig. 1). In the phylogenetic analyses inferred from tuf, dnaJ and rpoB gene sequence comparisons, strain $5402776^{\mathrm{T}}$ clustered with $S$. pettenkoferi (see Supplementary Figs S1, S2 and S3 in IJSEM Online). The sequence similarity values were $93.7 \%, 82.5 \%$ and $89 \%$, respectively. In the phylogenetic analysis inferred from sodA gene sequences, strain $5402776^{\mathrm{T}}$ clustered with $S$. chromogenes $(82.8 \%)$ and in the phylogenetic analysis inferred from the $h s p 60$ gene sequences, strain $5402776^{\mathrm{T}}$ formed a distinct subline within the genus Staphylococcus (see Supplementary Figs S4 and S5).

Based on the results described above, we suggest that the novel strain isolated from a human brain abscess represents a novel species of the genus Staphylococcus species, for which the name Staphylococcus massiliensis sp. nov. is proposed.

\section{Description of Staphylococcus massiliensis sp. nov.}

Staphylococcus massiliensis (mas.si.li.en'sis. L. masc. adj. massiliensis of Massilia, the old Roman name for Marseille, from where the type strain was isolated).

Cells are Gram-positive, $0.5-0.8 \mu \mathrm{m}$ in diameter, nonspore-forming, non-motile and occur singly, in pairs and in clusters. Growth occurs preferentially in aerobic atmospheres. After $48 \mathrm{~h}$ on $5 \%$ sheep blood agar, colonies are white, glossy, circular, regular, bulged, non-haemolytic and $1-3 \mathrm{~mm}$ in diameter. The temperature range for growth is $25-45{ }^{\circ} \mathrm{C}$, with optimum growth between $30{ }^{\circ} \mathrm{C}$ and $37{ }^{\circ} \mathrm{C}$. Grows at $37{ }^{\circ} \mathrm{C}$ in TSB containing $0-15 \%$ (w/v) $\mathrm{NaCl}$. Coagulase-negative, catalase-positive, oxidase-negative, novobiocin-susceptible and negative in tests for the presence of clumping factor. Using API ZYM, activities of esterase (C4) and esterase lipase (C8) are weakly positive. No activities for alkaline phosphatase, lipase (C14), acid phosphatase, $\beta$ galactosidase, leucine arylamidase, valine arylaminidase, $\alpha$-glucosidase, cystine arylaminidase, trypsin, $\alpha$-chymotrypsin, naphthol-AS-BI-phosphohydrolase, $\alpha$-galactosidase, $\beta$-glucuronidase, $\beta$-glucosidase, $N$-acetyl- $\beta$-glucosaminidase, $\alpha$ mannosidase or $\alpha$-fucosidase are detected. Using the API Rapid ID32 Staph system, reduction of nitrates is positive. No activities for urease, arginine dihydrolase, ornithine decarboxylase, $\beta$-galactosidase, arginine arylamidase, alkaline phosphatase, pyrrolidonyl arylamidase or $\beta$-glucuronidase. Negative results for aesculin hydrolysis and acetoin production. All reactions for fermentation of sugars are negative: D-glucose, D-fructose, D-mannose, D-lactose, trehalose, Dmannitol, raffinose, D-ribose, cellobiose, D-sucrose, turanose, $\mathrm{N}$-acetylglucosamine and L-arabinose. Using API $50 \mathrm{CH}$ after an incubation time of $48 \mathrm{~h}$, acid is not produced from D- 


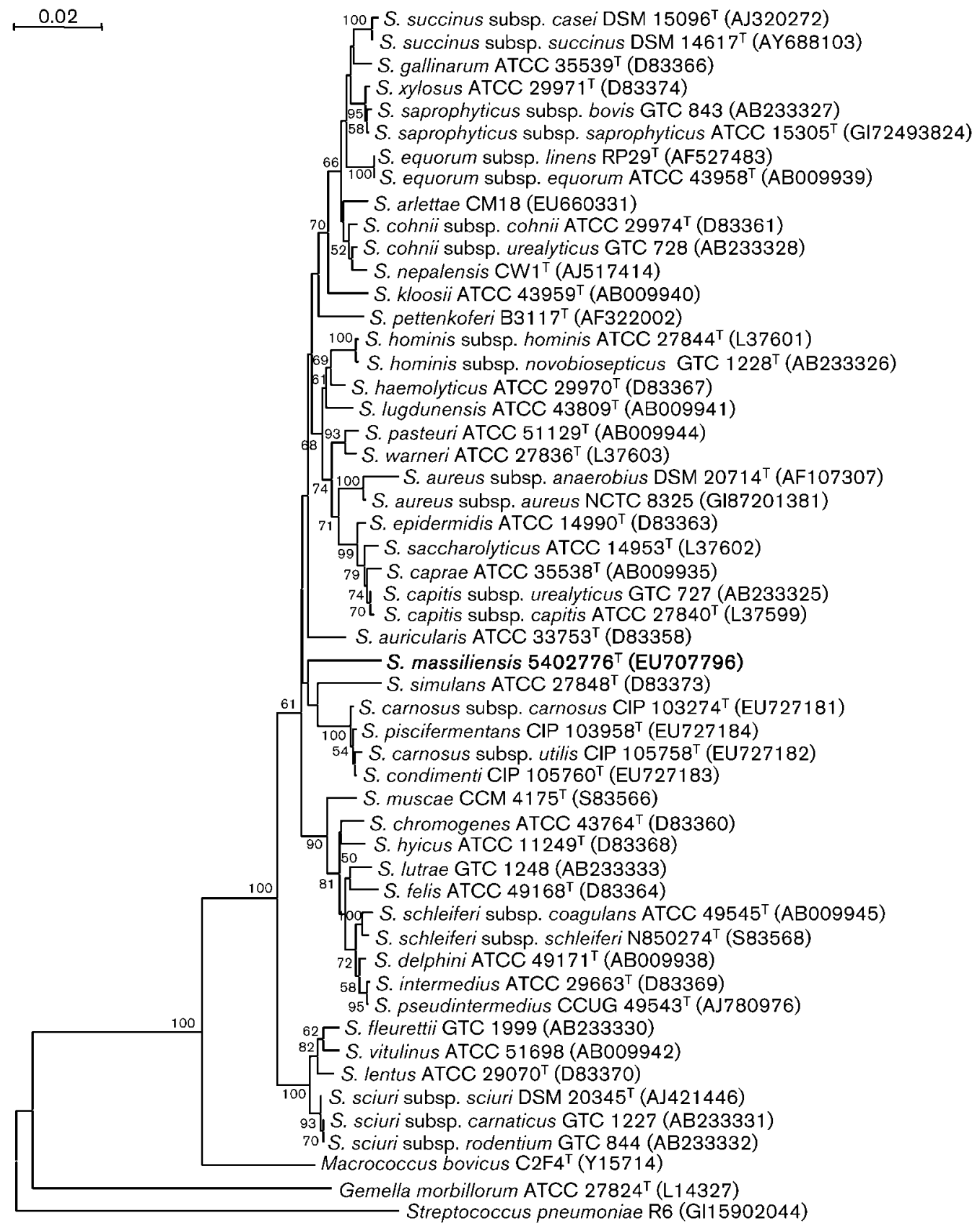

Fig. 1. Phylogenetic tree inferred from $16 \mathrm{~S}$ rRNA gene sequence comparisons (1264 nt fragment). Numbers at nodes are the percentages of 100 resamplings that support the shown topology. Macrococcus bovicus, Gemella morbillorum and Streptococcus pneumoniae were used as the outgroup. Bootstrap values $>50 \%$ are indicated at nodes. Bar, 0.02 nucleotide changes per nucleotide position.

galactose, D-glucose, D-fructose, maltose, D-lactose, sucrose, trehalose, D-xylose, melezitose, turanose, D-lyxose, D-ribose, D-mannose, glycerol, erythritol, D-arabinose, L-arabinose, L-xylose, D-adonitol, methyl $\beta$-D-xylopyranoside, L-sorbose, L-rhamnose, dulcitol, inositol, D-mannitol, D-sorbitol, methyl $\alpha$-D-mannopyranoside, methyl $\alpha$-D-glucopyranoside, $N$ acetylglucosamine, amygdalin, arbutin, aesculin ferric citrate, salicin, cellobiose, D-melibiose, inulin, raffinose, starch, glycogen, xylitol, gentiobiose, D-tagatose, D-fucose, L-fucose, D-arabitol, L-arabitol, potassium gluconate, potassium 2ketogluconate or potassium 5-ketogluconate. Using the Biolog GP2 Microplate, the following tests are positive, $\alpha$-Dglucose, D-ribose, $\alpha$-ketovaleric acid, L-lactic acid, pyruvic acid methyl ester, pyruvic acid, L-alanine, L-glutamic acid, Lpyroglutamic acid, L-serine, glycerol, adenosine and $2^{\prime}$ deoxyadenosine. L-Arabinose and inosine are weakly posi- 
tive. $\mathrm{L}$-Alaninamide is variable. The following tests are negative: $\alpha$-cyclodextrin, $\beta$-cyclodextrin, dextrin, glycogen, inulin, mannan, Tween 40 , Tween $80, \mathrm{~N}$-acetyl-D-glucosamine, $N$-acetyl- $\beta$-D-mannosamine, amygdalin, D-arabitol, arbutin, cellobiose, D-fructose, L-fucose, D-galactose, D-galacturonic acid, gentiobiose, D-gluconic acid, myo-inositol, $\alpha$-D-lactose, lactulose, maltose, maltotriose, D-mannitol, D-mannose, melezitose, melibiose, methyl $\alpha$-D-galactoside, methyl $\beta$-Dgalactoside, 3 -methyl D-glucose, methyl $\alpha$-D-glucoside, methyl $\beta$-D-glucoside, methyl $\alpha$-D-mannoside, palatinose, D-psicose, raffinose, L-rhamnose, salicin, sedoheptulosan, Dsorbitol, stachyose, sucrose, D-tagatose, trehalose, turanose, xylitol, D-xylose, acetic acid, $\alpha$-hydroxybutyric acid, $\beta$ hydroxybutyric acid, $\gamma$-hydroxybutyric acid, $p$-hydroxyphenylacetic acid, $\alpha$-ketoglutaric acid, lactamide, D-lactic acid methyl ester, D-malic acid, L-malic acid, succinic acid monomethyl ester, propionic acid, succinamic acid, succinic acid, $\mathrm{N}$-acetyl-L-glutamic acid, D-alanine, L-alanyl glycine, Lasparagine, glycyl L-glutamic acid, putrescine, 2,3-butanediol, thymidine, uridine, adenosine $5^{\prime}$-monophosphate, thymidine 5'-monophosphate, uridine 5'-monophosphate, D-fructose 6-phosphate, $\alpha$-D-glucose 1-phosphate, D-glucose 6-phosphate and DL- $\alpha$-glycerol phosphate. The respiratory quinones are MK-7 (93\%) and MK-6 (7\%), and the major fatty acids are $\mathrm{C}_{15: 0}$ iso, $\mathrm{C}_{17: 0}$ iso, $\mathrm{C}_{15: 0}$ anteiso and $\mathrm{C}_{19: 0}$ iso. The peptidoglycan type is $\mathrm{A} 3 \alpha$ L-Lys-Gly $2-3-\mathrm{L}-\mathrm{Ser}-\mathrm{Gly}$.

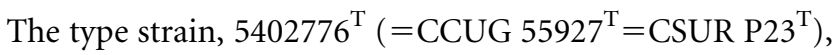
was isolated from a human brain abscess. The DNA G $+C$ content of the type strain was $36.6 \mathrm{~mol} \%$.

\section{Acknowledgements}

We are grateful to Bernard Campagna and Nicolas Aldrovandi for their technical assistance with electronic microscopy.

\section{References}

Achtman, M. \& Wagner, M. (2008). Microbial diversity and the genetic nature of microbial species. Nat Rev Microbiol 6, 431440.

Ghebremedhin, B., Layer, F., König, W. \& König, B. (2008). Genetic classification and distinguishing of Staphylococcus species based on different partial gap, $16 \mathrm{~S}$ rRNA, hsp60, rpoB, sodA, and tuf gene sequences. J Clin Microbiol 46, 1019-1025.

Huebner, J. \& Goldmann, D. A. (1999). Coagulase-negative staphylococci: role as pathogens. Annu Rev Med 50, 223-236.

Kimura, M. (1980). A simple method for estimating evolutionary rates of base substitutions through comparative studies of nucleotide sequences. J Mol Evol 16, 111-120.

Kuisiene, N., Raugalas, J., Spröer, C., Kroppenstedt, R. M. \& Chitavichius, D. (2008). Bacillus butanolivorans sp. nov., a species with industrial application for the remediation of n-butanol. Int J Syst Evol Microbiol 58, 505-509.

MacKenzie, S. L. (1987). Gas chromatographic analysis of amino acids as the N-heptafluorobutyryl isobutyl esters. J Assoc Off Anal Chem 70, 151-160.
Mesbah, M., Premachandran, U. \& Whitman, W. B. (1989). Precise measurement of the $\mathrm{G}+\mathrm{C}$ content of deoxyribonucleic acid by highperformance liquid chromatography. Int J Syst Bacteriol 39, 159167.

Mun, H. S., Park, J. H., Kim, H., Yu, H. K., Park, Y. G., Cha, C. Y., Kook, Y. H. \& Kim, B. J. (2008). Mycobacterium senuense sp. nov., a slowly growing, non-chromogenic species closely related to the Mycobacterium terrae complex. Int J Syst Evol Microbiol 58, 641646.

Pantůček, R., Sedláček, I., Petrás, P., Koukalová, D., Švec, P., Štětina, V., Vancanneyt, M., Chrastinová, L., Vokurková, J. \& other authors (2005). Staphylococcus simiae sp. nov., isolated from South American squirrel monkeys. Int J Syst Evol Microbiol 55, 19531958.

Saitou, N. \& Nei, M. (1987). The neighbor-joining method: a new method for reconstructing phylogenetic trees. Mol Biol Evol 4, 406425.

Schleifer, K. H. (1985). Analysis of the chemical composition and primary structure of murein. Methods Microbiol 18, 123156.

Schleifer, K. H. \& Kandler, O. (1972). Peptidoglycan types of bacterial cell walls and their taxonomic implications. Bacteriol Rev 36, 407477.

Shah, M. M., lihara, H., Noda, M., Song, S. X., Nhung, P. H., Ohkusu, K., Kawamura, Y. \& Ezaki, T. (2007). dnaJ gene sequence-based assay for species identification and phylogenetic grouping in the genus Staphylococcus. Int J Syst Evol Microbiol 57, 25-30.

Song, Y., Liu, C. \& Finegold, S. M. (2007). Peptoniphilus gorbachii sp. nov., Peptoniphilus olsenii sp. nov. and Anaerococcus murdochii sp. nov. isolated from clinical specimens of human origin. J Clin Microbiol 45, 1746-1752.

Spergser, J., Wieser, M., Täubel, M., Rosselló-Mora, R. A., Rosengarten, R. \& Busse, H. J. (2003). Staphylococcus nepalensis sp. nov., isolated from goats of the Himalayan region. Int J Syst Evol Microbiol 53, 2007-2011.

Stackebrandt, E. \& Ebers, J. (2006). Taxonomic parameters revisited: tarnished gold standards. Microbiol Today 33, 152-155.

Stackebrandt, E., Frederiksen, W., Garrity, G. M., Grimont, P. A. D., Kämpfer, P., Maiden, M. C. J., Nesme, X., Rossello-Mora, R., Swings, J. \& other authors (2002). Report of the ad hoc committee for the reevaluation of the species definition in bacteriology. Int J Syst Evol Microbiol 52, 1043-1047.

Tamura, K., Dudley, J., Nei, M. \& Kumar, S. (2007). MEGA4: Molecular evolutionary genetics analysis (MEGA) software version 4.0. Mol Biol Evol 24, 1596-1599.

Tindall, B. J. (1990a). A comparative study of the lipid composition of Halobacterium saccharovorum from various sources. Syst Appl Microbiol 13, 128-130.

Tindall, B. J. (1990b). Lipid composition of Halobacterium lacusprofundi. FEMS Microbiol Lett 66, 199-202.

Trülzsch, K., Grabein, B., Schumann, P., Mellmann, A., Antonenka, U., Heesemann, J. \& Becker, K. (2007). Staphylococcus pettenkoferi sp. nov., a novel coagulase-negative staphylococcal species isolated from human clinical specimens. Int J Syst Evol Microbiol 57, 15431548.

Von Eiff, C., Peters, G. \& Heilmann, C. (2002). Pathogenesis of infections due to coagulase-negative staphylococci. Lancet Infect Dis $\mathbf{2}$, 677-685.

Weisburg, W. G., Barns, S. M., Pelletier, D. A. \& Lane, D. J. (1991). 16 S ribosomal DNA amplification for phylogenetic study. J Bacteriol 173, 697-703. 
Zakrzewska-Czerwinska, J., Gaszewska-Mastalarz, A., Lis, B., Gamian, A. \& Mordarski, M. (1995). Staphylococcus pulvereri sp. nov., isolated from human and animal specimens. Int J Syst Bacteriol 45, 169-172.
Zhou, G., Luo, X., Tang, Y., Zhang, L., Yang, Q., Qiu, Y. \& Fang, C. (2008). Kocuria flava sp. nov. and Kocuria turfanensis sp. nov., airborne actinobacteria isolated from Xinjiang, China. Int J Syst Evol Microbiol 58, 1304-1307. 